\title{
Enalapril reduces microalbuminuria in young normotensive Type 1 (insulin-dependent) diabetic patients irrespective of its hypotensive effect
}

\author{
S. Rudberg, A. Aperia, U.Freyschuss and B.Persson \\ Department of Paediatrics, St. Göran's Children's Hospital, Karolinska Institute, Stockholm, Sweden
}

\begin{abstract}
Summary. The effect of enalapril on albumin excretion rate was studied in two groups of age- and sex-matched Type 1 (insulin-dependent) diabetic patients, aged $15-20$ years, with persistent microalbuminuria $>20 \mu \mathrm{g} /$ min. Group 1 contained six patients with systolic blood pressure $\geq 75$ th percentile for age and sex, group 2 six normotensive patients. Enalapril (10-20 mg/day) was given for six months. Albumin excretion rate, glomerular filtration rate, renal plasma flow, blood pressure at rest and during exercise, and angiotensin converting enzyme activity were measured before, after three weeks' and six months' treatment and six months after treatment withdrawal. Albumin excretion rate decreased in all patients after three weeks' (mean decreases 55\% in group 1, $65 \%$ in group 2) and six months' treatment (35\% in group 1, $61 \%$ in group 2). Systolic blood pressure remained unchanged in both groups. Diastolic pressure was reduced after three weeks in group $1(p=0.001)$. No reduction in increment in systolic pressure during exercise test occurred in any group during treatment. Angiotensin converting enzyme activity
\end{abstract}

decreased in all patients after three weeks $(p=0.001)$ and six months $(p=0.003)$. This correlated to the decrease in albumin excretion rate after three weeks $(r=0.79, p=0.05)$ and six months $(r=0.59, p=0.04)$. $\mathrm{HbA}_{\mathfrak{l c}}$, mean blood glucose and glomerular filtration rate remained unchanged during the study in both groups. Renal plasma flow tended to increase after three weeks' and six months' treatment in group 2 $(p=0.06$, respectively) but not in group 1 . Filtration fraction decreased after three weeks $(p=0.04)$ only in group 2 . In conclusion, enalapril reduces the albumin excretion rate in adolescent diabetic patients with or without elevated blood pressure. This reduction was not accompanied by a decreased systemic pressure but rather by a fall in filtration fraction in normotensive patients, indicating a direct effect, irrespective of the antihypertensive, on intraglomerular pressure.

Key words: Albumin excretion rate, angiotensin converting enzyme inhibitor, blood pressure, Type 1 (insulin-dependent) diabetes.
Persistent microalbuminuria strongly predicts subsequent overt diabetic nephropathy $[1,2]$. Type 1 (insulin-dependent) patients with onset of diabetes before 20 years of age seem to be at highest risk [3]. Incipient nephropathy, i.e. persistent elevated albumin excretion rate between 20 and $200 \mu \mathrm{g} / \mathrm{min}$, is accompanied by an increase in the prevalence of arterial hypertension [3,4]. Nevertheless, many patients with incipient nephropathy remain normotensive [2]. A positive correlation between microalbuminuria and arterial pressure has also been found in normotensive diabetic patients with incipient nephropathy $[5,6]$. Thus, the early institution of antihypertensive treatment is one possible way to delay the development of diabetic nephropathy [7]. The reduction in blood pressure must be initiated at an earlier stage in the development of hypertension in diabetic than in nondiabetic patients in order to reduce the risk of renal damage [8].

Interest has focussed on the use of angiotensin converting enzyme inhibitors because of their beneficial renal haemodynamic effects, as demonstrated in diabetic rats [9]. Treatment of adult normotensive humans with Type 1 diabetes and incipient nephropathy with $\mathrm{ACE}$ inhibitors reduces microalbuminuria $[10,11]$. In a short-term study ( $24 \mathrm{~h}$ ) of the effect of captopril on exercise-induced microalbuminuria in normotensive patients with Type 1 diabetes, a significant reduction in the albumin excretion rate was seen although the systemic blood pressure was not affected [12]. Otherwise, no data have been published concerning any beneficial effect of ACE-inhibition on 
Table 1. Clinical characteristics of 12 Type 1 (insulin-dependent) diabetic patients. Group 1: blood pressure $\geq 75$ th percentile, group 2: blood pressure $<75$ th percentile. Mean \pm SD (range)

\begin{tabular}{|c|c|c|}
\hline & $\begin{array}{l}\text { Group } 1 \\
(n=6)\end{array}$ & $\begin{array}{l}\text { Group } 2 \\
(n=6)\end{array}$ \\
\hline Age (year) & $\begin{array}{l}18.7 \pm 1.0 \\
(17-20)\end{array}$ & $\begin{array}{l}18.6 \pm 2.1 \\
(15-20)\end{array}$ \\
\hline Duration of diabetes (years) & $\begin{array}{l}7.8 \pm 2.0 \\
(5-11)\end{array}$ & $\begin{array}{l}12.5 \pm 3.3 \\
(9-18)\end{array}$ \\
\hline Onset of diabetes (years) & $\begin{array}{l}10.0 \pm 3.2 \\
(6-12)\end{array}$ & $\begin{array}{l}6.2 \pm 2.9 \\
(1-10)\end{array}$ \\
\hline \multicolumn{3}{|l|}{ Blood pressure $(\mathrm{mmHg})$} \\
\hline Systolic & $\begin{array}{l}135 \pm 5 \\
(130-140)\end{array}$ & $\begin{array}{l}113 \pm 10 \\
(100-125)\end{array}$ \\
\hline Diastolic & $\begin{array}{l}85 \pm 5 \\
(80-90)\end{array}$ & $\begin{array}{l}72 \pm 7 \\
(60-80)\end{array}$ \\
\hline $\begin{array}{l}\text { Albumin excretion rate }\left(\mu \mathrm{g} \cdot \mathrm{min}^{-1}\right) \\
\text { (median) }\end{array}$ & $\begin{array}{l}26 \\
(20-51)\end{array}$ & $\begin{array}{l}30 \\
(21-237)\end{array}$ \\
\hline $\begin{array}{l}\text { Glomerular filtration rate } \\
\left(\mathrm{ml} \cdot \mathrm{min}^{-1} \cdot 1.73 \mathrm{~m}^{-2}\right)\end{array}$ & $\begin{array}{l}130 \pm 24 \\
(103-170)\end{array}$ & $\begin{array}{l}125 \pm 20 \\
(104-155)\end{array}$ \\
\hline $\begin{array}{l}\text { Renal plasma flow } \\
\left(\mathrm{ml} \cdot \mathrm{min}^{-1} \cdot 1.73 \mathrm{~m}^{-2}\right)\end{array}$ & $\begin{array}{l}627 \pm 193 \\
(414-1078)\end{array}$ & $\begin{array}{l}581 \pm 113 \\
(472-696)\end{array}$ \\
\hline $\mathrm{HbA}_{1 \mathrm{c}}(\%)$ & $\begin{array}{l}6.7 \pm 1.5 \\
(4.8-8.5)\end{array}$ & $\begin{array}{l}8.5 \pm 3.1 \\
(6.0-13.6)\end{array}$ \\
\hline Insulin dose (IU/kg) & $\begin{array}{l}0.8 \pm 0.1 \\
(0.6-1.0)\end{array}$ & $\begin{array}{l}0.9 \pm 0.2 \\
(0.7-1.2)\end{array}$ \\
\hline Body weight (kg) & $\begin{array}{l}74.6 \pm 10.6 \\
(61.0-87.5)\end{array}$ & $\begin{array}{l}65.4 \pm 12.8 \\
(51.0-85.0)\end{array}$ \\
\hline Height $(\mathrm{cm})$ & $\begin{array}{l}182 \pm 5.5 \\
(173-188)\end{array}$ & $\begin{array}{l}172 \pm 9.5 \\
(163-187)\end{array}$ \\
\hline
\end{tabular}

renal function in diabetic patients, irrespective of its hypotensive effect for a longer period.

Hypertension in adult patients with diabetes mellitus is defined as a mean value of two or more blood pressure measurements exceeding $140 / 90 \mathrm{~mm} \mathrm{Hg}$ [8].

The aim of this study was to evaluate the effect of a sixmonth period of ACE-inhibition on microalbuminuria in two groups of teenage subjects with Type 1 diabetes and incipient nephropathy. One group had systolic blood pressure above the 75 th percentile, which corresponds to the values regarded as elevated blood pressure in adult diabetic patients [8]. The other group had blood pressure below this level [13]. The purpose of this division was to investigate whether the effect of treatment with ACE inhibition on microalbuminuria might be due to an effect on isolated renal hypertension or if it was correlated only to a fall in systemic blood pressure.

\section{Subjects and methods}

\section{Subjects}

Twelve patients participated in the study, all of whom had microalbuminuria defined as two consecutive overnight or 24-h collected urine samples with an albumin excretion rate (AER) of $20 \mu \mathrm{g} /$ min or more. Six patients (group 1, one female, five males) had a systolic blood pressure above the 75 th percentile for age and sex [13] measured at least twice and six patients had systolic and diastolic blood pressures below this value (group 2, one female and five males). The groups were comparable with regard to age and sex (Table 1). All clinical characteristics are given in Table 1.

Eleven patients were treated with three four s.c. insulin injections daily and one patient with continuous s.c. insulin infusion. No patient was on a low protein diet. The sodium intake was not regulated. No medication other than insulin had been prescribed during the month preceding the study. During the study the only drug used apart from insulin was enalapril.

\section{Study protocol}

Informed consent to participate in the study was given by patients and parents. The study was approved by the local ethics committee.

Schedule. The patients were followed for six months while they were taking enalapril and for six months after they had discontinued taking this medication. All the examinations were performed on the day before commencement of treatment with enalapril and after three weeks and six months of treatment. Finally, the patients were examined six months after they had stopped taking enalapril.

Treatment. Treatment with enalapril was started the day after the initial renal function test using a dose of $0.25-0.35 \mathrm{mg} \cdot \mathrm{kg}^{-1}$, i.e., $20 \mathrm{mg} \cdot \mathrm{day}^{-1}$. The drug was taken once a day in the morning for a period of six months. The dose was adjusted because of slight side-effects in two patients who after a few days treatment, complained of fatigue. The enalapril dose was reduced to 10 and $15 \mathrm{mg} \cdot \mathrm{kg}^{-1}$, respectively, in these patients.

The evaluation of compliance with the treatment was based on measurements of converting enzyme (ACE) activity during each renal function test.

Examinations. The renal function tests were performed between 09.00-12.00 hours. The patients had taken their ordinary insulin dose and breakfast at home. Glomerular filtration rate, renal plasma flow and filtration fraction (FF) were determined. The albumin excretion rate in overnight urine samples collected at home on the night before the renal function test, and the AER during the clearance study were determined. The AER was also analysed in overnight urine after three months' treatment. Systolic and diastolic blood pressures were measured in the left arm by the same observer, with the patient in sitting position after $15 \mathrm{~min}$ rest, before each clearance study.

Metabolic control was determined by $\mathrm{HbA}_{1 c}$ and mean blood glucose was calculated from four blood samples taken during the clearance study. Measurements of free insulin in serum were made on the same occasions. These were performed because it has been proposed that hyperinsulinaemia plays a role in the increase in blood pressure in diabetic patients [14]. The fractional sodium excretion in urine was analysed during the clearance study.

The ACE activity and aldosterone levels in serum were followed. Because of sampling errors, ACE activity and aldosterone were analysed in only eight patients (four from each group) on the initial examination and after three weeks of enalapril administration.

Urinary phosphate excretion was analysed during the clearance study to exclude the influence of changes in protein intake on renal function [15].

Physical exercise tests were carried out in order to emphasize the effects of ACE-inhibition on systolic blood pressure. A bicycle ergometry test was performed on the afternoon of the day before the clearance studies. The workload was increased stepwise by 30 40 watt every 4 th $\mathrm{min}$. The final workload was standardized to approximately $90 \%$ of the maximal oxygen consumption [16] and was also maintained for $4 \mathrm{~min}$. Heart rate and blood pressure (using a 


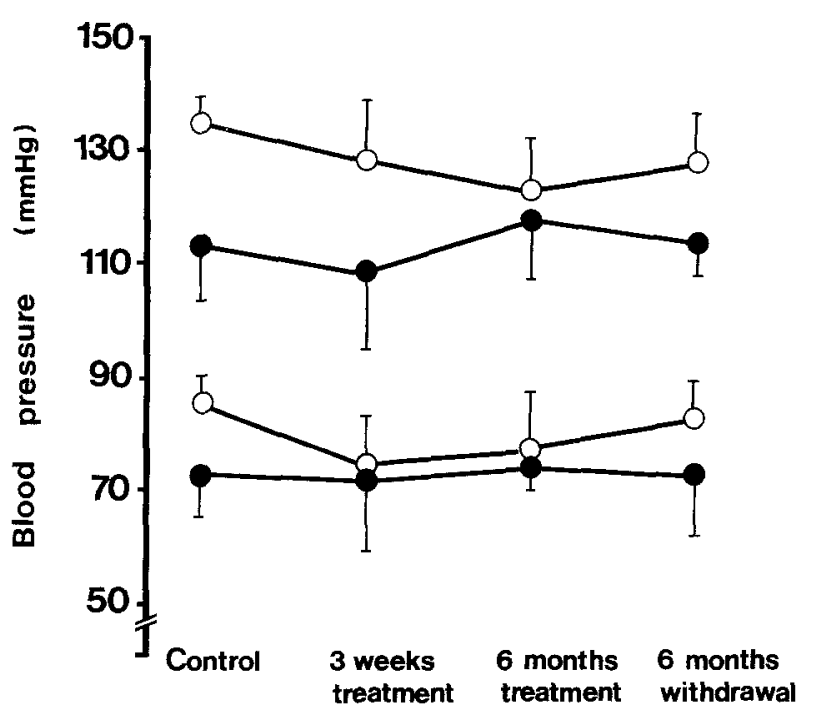

Fig. 1. Systolic and diastolic blood pressures before, during and after enalapril treatment. Open circles indicate group 1 and filled circles group 2. Upper part of the figure illustrates systolic blood pressure and lower part diastolic blood pressure

torniquet of appropriate size) were measured at rest and at every step. One of the patients did not participate in the physical exercise tests. This patient also chose to continue with enalapril after the prescribed six months and was therefore excluded from the final renal examination without treatment.

\section{Analytical methods}

The glomerular filtration rate and renal plasma flow $\left(\mathrm{ml} \cdot \mathrm{min}^{-1}\right.$. $1.73 \mathrm{~m}^{2-1}$ ) were measured by administering a continuous infusion of inulin (Inulin, Laevosan, Linz, Austria) [17] and p-aminohippuric acid (PAH, Merck Sharp and Dohme, Rahway, NJ, USA) [18]. The patients were given tap water to drink in a prime dose of $20 \mathrm{ml} \cdot \mathrm{kg}^{-1}$ for $1 \mathrm{~h}$ and were then given $5 \mathrm{ml} \cdot \mathrm{kg}^{-1}$ every $30 \mathrm{~min}$. After the storage of the urine samples at $-20^{\circ} \mathrm{C}$ and before analysis of p-aminohippuric acid, the urine $(200 \mu \mathrm{l})$ was mixed with concentrated $\mathrm{HCl}(10 \mu \mathrm{l})$ and heated to $70^{\circ} \mathrm{C}$ for $10 \mathrm{~min}$. This was performed to resolve a probable Schiff base reaction of p-aminohippuric acid and glucose which leads to a decline in the clearance of $\mathrm{p}$-aminohippuric acid in patients with glucosuria [19].

FF (\%) was calculated as the glomerular filtration rate/renal plasma flow.

AER $\left(\mu \mathrm{g} \cdot \mathrm{min}^{-1}\right)$ was measured by RIA (Phadebas, Uppsala, Sweden). Determination of AER was performed in samples obtained from both overnight-collected urine and from four samples of urine collected during the clearance studies 60-150 min after the initial hydration. Fractional albumin clearance was estimated and calculated as the clearance of albumin/clearance of inulin.

Blood pressure $(\mathrm{mm} \mathrm{Hg}$ ) was measured using a conventional sphygmomanometer and diastolic blood pressure was read at phase 5.

Blood glucose $\left(\mathrm{mmol} \cdot \mathrm{l}^{-1}\right)$ was analysed by an enzymatic method (Gluc-DH, Merck, Darmstadt West, Germany).

$\mathrm{HbA}_{\mathrm{cc}}(\%)$ was determined by high-pressure liquid chromatography (Auto-A, Kyoto-Daiichi, Kagaku Co, Ltd, Japan).

ACE activity (normal range 18-55 Units) was analysed in serum using an RIA method (Buhlman Laboratories AG, Basel, Switzerland).

Aldosterone in serum $\left(\mathrm{pmol} \cdot \mathrm{1}^{-1}\right.$ ) was analysed by an RIA method (Diagnostic Products Corporation, Los Angeles, Calif., USA).

Free insulin in serum $\left(\mathrm{nmol} \cdot 1^{-1}\right)$ was analysed by an RIA method (Novo Research Institute, Bagsvaerd, Denmark).

Urinary phosphate excretion in urine $\left(\mathrm{mmol} \cdot \mathrm{h}^{-1}\right)$ was measured in four urine samples during the renal function tests [20]. Fractional sodium excretion was calculated as the clearance of sodium/clearance of inulin, and sodium excretion was analysed using a flamometer (Kontron, Stockholm, Sweden).

\section{Statistical analysis}

All values are expressed as means $\pm \mathrm{SD}$ if not otherwise stated.

For the analyses of AER, ACE activity and aldosterone logtransformed values were used because of the skewed distributions. The statistical methods employed were one-way analysis of variance (ANOVA) to assess the effects of treatment at different times, Student's $t$-test for comparisons between groups and the Pearson or Spearman methods for correlation studies. A $p$ value less than 0.05 was considered to be statistically significant.

Table 2. Glomerular filtration rate, renal plasma flow, filtration fraction, albumin excretion rate, clearance of sodium $\left(\mathrm{C}_{\mathrm{Na}} / \mathrm{C}_{\mathrm{NN}}\right), \mathrm{Hb} \mathrm{A}_{1 \mathrm{c}}$, mean blood glucose during clearance investigation, before, during and after enalapril treatment. Group $1(n=6)$ : patients with blood pressure $\geq 75$ th percentile. Group $2(n=6)$ : blood pressure $<75$ th percentile. Mean \pm SD

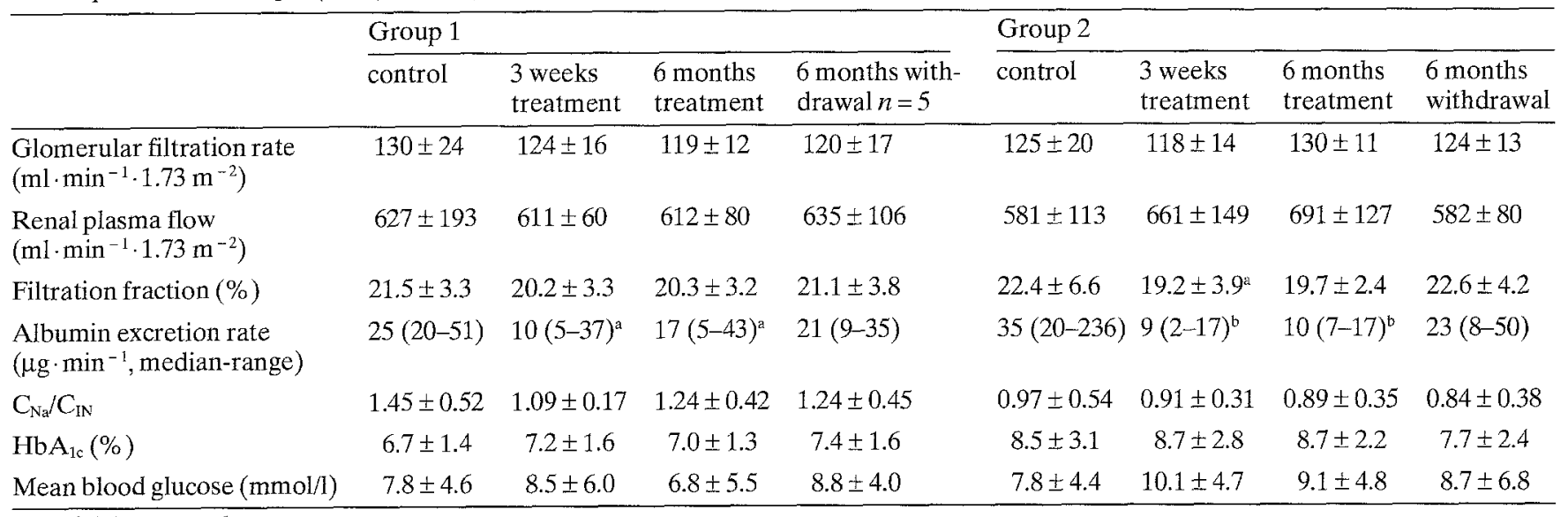

${ }^{a} p<0.05$ vs control

b $p<0.005$ vs control 


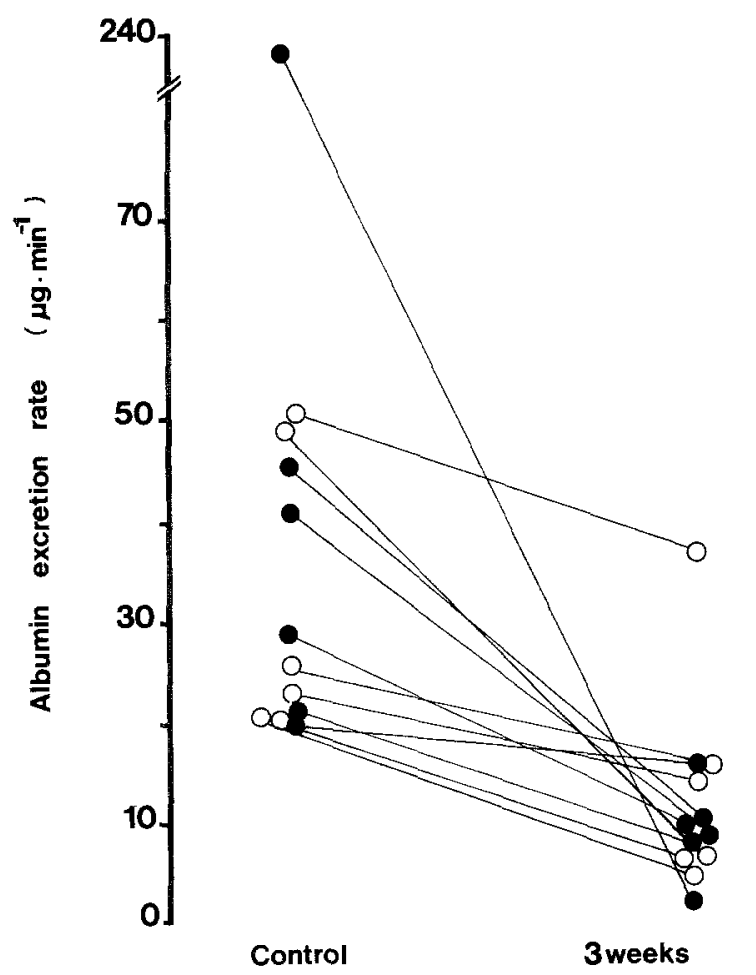

Fig. 2. Albumin excretion rate before and after three weeks' treatment with enalapril. Open circles indicate group 1 and filled circles group 2

\section{Results}

The groups differed from each other with regard to duration and age at onset of diabetes. Patients with blood pressure below the 75th percentile had a somewhat longer duration ( $p=0.01)$ and were younger at onset of diabetes $(p=0.02)$. All other clinical characteristics such as GFR, RPF, AER, $\mathrm{HbA}_{1 \mathrm{c}}$, insulin dose, age, weight, and height were similar in both groups (Table 1 ).

\section{Blood pressure}

Group 1. Diastolic blood pressure decreased by a mean of $8 \pm 3 \mathrm{~mm} \mathrm{Hg}$ after three weeks' treatment with enalapril in all patients in group $1(p=0.001)$. After six months' treatment the decrease was not statistically significant when compared to initial values (Fig. 1). After six months without treatment diastolic blood pressure rose in all patients except one who had an unchanged pressure $(p=0.18)$. No significant change in the systolic blood pressure was seen during treatment (Fig. 1).

Group 2. No changes were seen either in the systolic $(p=0.47)$ or the diastolic $(p=0.9)$ blood pressure in this group (Fig. 1).

\section{Albumin excretion rate}

Group 1. AER decreased in all the patients after three weeks' as well as after six months' enalapril treatment when compared to the initial values $(p=0.02$ and $p=0.04$,
Table 2, Fig. 2). After three months' treatment AER was equally decreased $8(3-22) \mu \mathrm{g} \cdot \min ^{-1}(p=0.02)$. The mean decrease between the first and the second examination was $55 \%$ in group 1 . After six months the corresponding figure was $35 \%$.

Fractional albumin clearance decreased in all patients after three weeks of enalapril treatment, from $0.98 \cdot 10^{-6}$ to $0.54 \cdot 10^{-6}(p=0.04)$. After six months, the corresponding value was $0.53 \cdot 10^{-6}(p=0.03)$. Following six months without treatment, fractional albumin clearance rose again, as compared to the third examination, to $0.69 \cdot 10^{-6}$.

Group 2. Following treatment with enalapril, all the patients reduced their AER both after three weeks and after six months ( $p=0.001$ and $p=0.003$ ), respectively (values presented in Fig. 2, Table 2), as well as after three months' treatment, $8(4-32) \mu \mathrm{g} \cdot \min ^{-1}(p=0.003)$. The mean decrease was $65 \%$ after three weeks' and $61 \%$ after six months' use of enalapril.

The fractional albumin clearance decreased after three weeks from $1.59 \cdot 10^{-6}$ to $0.56 \cdot 10^{-6}(p=0.003)$. After six months the corresponding value was $0.56 \cdot 10^{-6}$ $(p=0.003)$. When treatment was stopped for six months the fractional albumin clearance rose to $0.78 \cdot 10^{-6}$.

\section{Angiotensin converting enzyme activity and serum aldosterone}

Individual figures for $\mathrm{ACE}$ activity before and after three weeks' treatment are presented in Figure 3. ACE activity was markedly reduced during enalapril treatment in both groups after three weeks, the median values for all patients being $19.5(6.0-54.9)$ vs $1.1(0.6-18.9)$ units, $p<0.001$. After six months' treatment ACE activity was still reduced, $2.1(0.4-51.1)$ units, $p=0.003$. After treatment was stopped ACE activity rose to 48.9 (35.2-71.9) units, which was not significantly different from the levels before treatment. A positive correlation between the decrease in ACE activity and AER was found both after three weeks' treatment with enalapril $(r=0.71, p=0.05)$ as well as after six months' $(r=0.59, p=0.04)$. A significant correlation was also seen between AER and ACE activity before enalapril $(r=0.41, p=0.03)$ and after three weeks of such treatment $(r=0.56, p<0.001)$. The aldosterone levels in serum remained unchanged throughout the study. The median value in all patients before treatment was 265 (196-540) pmol $\cdot 1^{-1}$ after three weeks s-aldosterone was 157 (80-584), after six months' treatment 226 (118-854) and finally after six months without medication $269(148-653) \mathrm{pmol}^{-1} \mathrm{l}^{-1}$.

\section{Kidney function tests}

Glomerular filtration rate remained unchanged in both groups during the study period (Table 2). Clearance of paminohippuric acid tended to increase in group 2 after three weeks' as well as after six months' use of enalapril (Table 2). No corresponding increase was noted in group 1 (Table 2 ). When analysing all data, we found that 

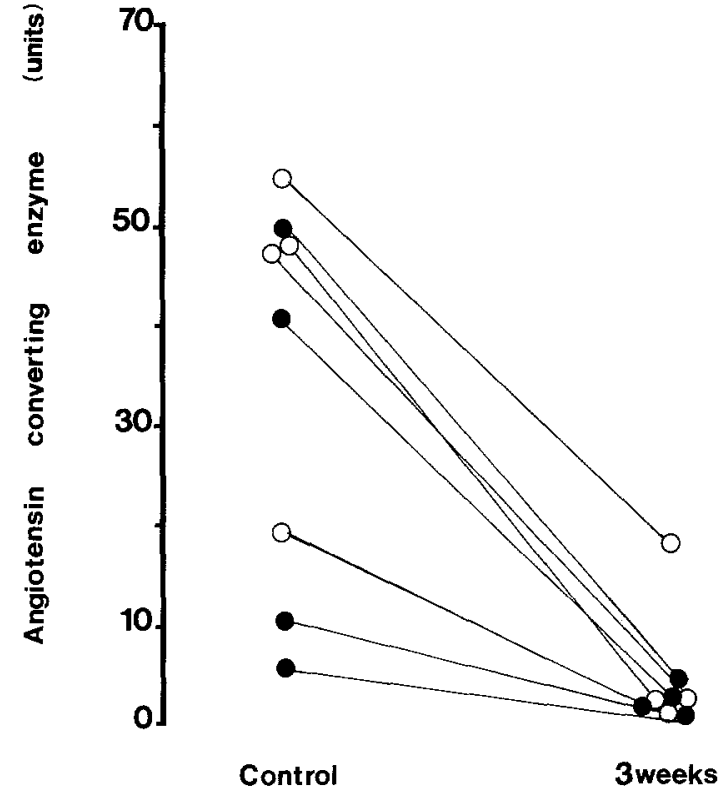

Fig.3. Angiotensin converting enzyme activity before and after three weeks' treatment with enalapril. Open circles indicate group 1 , filled circles group 2

the FF had declined from $21.4 \pm 4.9$ to $19.7 \pm 3.4(p=0.02)$ after three weeks and to $20.0 \pm 2.7(p=0.09)$ after six months. After enalapril withdrawal, FF rose to $22.0 \pm 3.9$ ( $p=0.02$ and $p=0.05$ as compared to values after three weeks' and six months' treatment, respectively). When analysing the groups separately FF remained unchanged during treatment in group 1 (Table 2). In group 2, however, FF had decreased after three weeks $(p=0.04$, Table 2), but this decrease was not statistically significant after six months $p=0.19$, Table 2). After treatment was stopped FF tended to increase as compared to after six months of treatment $(p=0.07)$. Values are presented in Table 2.

\section{Metabolic control}

During the study $\mathrm{HbA}_{1 \mathrm{c}}$ did not change in any group (Table 2). The average $\mathrm{HbA}_{1 \mathrm{c}}$ values tended to be higher in group 2 than in group 1 but this difference was not statistically significant (initial examination $p=0.07$ ). Mean blood glucose values during clearance investigations also remained unchanged in both groups (Table 2). No change in mean body weight or in the mean dose of insulin occurred. The free insulin concentrations and sodium clearance in both groups remained unchanged. No correlation between free insulin and sodium clearance was seen. The urinary phosphate excretion was stable in both groups during the study.

\section{Physical exercise test}

The rise in systolic blood pressure during exercise was steeper in group 1 than in group 2, both without enalapril and after six months treatment ( $p=0.03$ respectively). Maximal workload did not differ between the groups ( $220 \pm 50$ watt in group 1 and $210 \pm 40$ watt in group 2). Reference values for systolic blood pressure during maximal exercise test in 20 healthy male control subjects, aged 15-22 years (using the same workload and method in our laboratory) are $181 \pm 15 \mathrm{mmHg}$. The increase in systolic blood pressure in control subjects is $55 \pm 14 \mathrm{~mm} \mathrm{Hg}$ (unpublished data). This is significantly lower than the rise in systolic blood pressure in group 1 but not in group 2, before treatment was started $(p<0.001)$.

In group 1 the mean increase in systolic blood pressure during exercise was less marked after three weeks' treatment with enalapril, though it was not statistically significant. After six months without the drug, the blood pressure reaction was unchanged (Table 3 ).

In group 2 no change in the increase in systolic blood pressure during exercise was noted (Table 3 ).

No significant increase in heart rate at maximal workload was observed in any group (Table 3).

\section{Discussion}

This study shows that the inhibition of angiotensin-converting enzyme activity is associated with a significant reduction in microalbuminuria in adolescent Type 1 diabetic patients with incipient nephropathy. This is in agreement with previous observations in adult patients [10-12]. It is well recognized that other antihypertensive drugs, following the decrease in systemic blood pressure, decrease albuminuria in hypertensive patients with incipient nephropathy $[7,21,22]$.

An effect on urinary albumin excretion after captopril treatment without any effect on blood pressure, has earlier been demonstrated in patients with overt diabetic ne-

Table 3. Systolic blood pressure and heart rate at rest (R) and at maximal work load (MWL) before, during and after enalapril treatment. Mean \pm SD

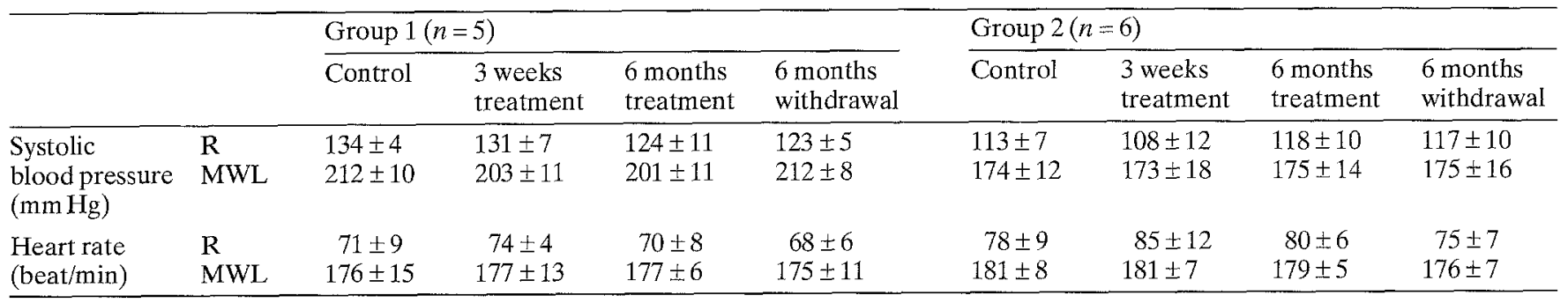


phropathy $[23,24]$. No similar observations in long-term studies of patients with incipient nephropathy have been published. Romanelli et al. [12], however, showed a reduction in the exercise-induced rise in albuminuria after short-term $(24 \mathrm{~h})$ administration of captopril in normotensive diabetic patients without affecting systemic blood pressure.

In the present study enalapril decreased AER both in patients with initial blood pressure at or above the 75th percentile as well as in those with blood pressure below this level. Marre et al. [10] also found a reduction in albuminuria in adult normotensive (i.e. with supine blood pressure below $160 / 95$ on three consecutive monthly measurements) Type 1- and Type 2 diabetic patients after 12 months' treatment with enalapril, but this was accompanied by a significant decrease in blood pressure. In the present study the decrease in diastolic blood pressure in group 1 may, of course, partly contribute to the decrease in AER among these patients. However, the similar decrease in AER in group 2 after ACE inhibition indicates an effect on microalbuminuria, irrespective of the hypotensive effect. This is further supported by the decrease in serum ACE activity seen in all our patients during enalapril treatment, and by the positive correlation between the change in ACE activity and AER. The reduced ACE activity also indicates good compliance with the medication.

Experimental studies in diabetic rats suggest that ACE inhibition reduces AER by decreasing the intraglomerular capillary pressure and the glomerular permeability to albumin [9]. This hypothesis is supported by the reduction in fractional albumin clearance seen in our study and in others [12]. The explanation that ACE inhibitors exert a direct effect on the ultrafiltration pressure by acting mainly on the efferent arterioli, is also supported in this study by the decrease in FF during treatment in group 2, without any change in blood pressure. Since a significant correlation was noted between AER and ACE activity before treatment was started one might wonder whether there is an increased density of angiotensin II receptors in patients with diabetes and microalbuminuria. It was recently proposed that angiotensin II, besides inducing mesangial contraction and increasing the passage of circulating macromolecules into the mesangium [25], also acts as a growth factor, stimulating glomerular hypertrophy [26]. One may therefore speculate that an effect of long-term ACE-inhibition on AER, without reduction in blood pressure, may partly be due to a decreased proliferation and reduced renal cellular growth stimulation. An experimental study in streptozotocin diabetic rats confirms that enalapril prevents glomerular basement thickening and albuminuria in both normo- and hypertensive subjects [27].

Significant natriuresis after ACE inhibition in normal subjects and hypertensive patients [28] as well as in diabetic patients without microalbuminuria [29] has been reported. In our study we were not able to confirm this, perhaps because the aldosterone levels remained unchanged.

Since fractional sodium excretion did not change in any group it is suggested that sodium balance probably does not affect AER.
The reduction in AER may also be due to changes in protein intake $[15,30,31]$ or to an improvement in blood glucose control [32]. The fact that urinary phosphate excretion remained stable suggests that protein intake was unchanged during the study period. The levels of $\mathrm{HbA}_{1 \mathrm{c}}$ and mean blood glucose remained unchanged during the study in both groups, hence excluding an influence of these factors on changes in AER.

Some patients with diabetes have been shown to have a labile systolic blood pressure with more marked increases during physical activity than are seen in healthy patients [33]. We found that patients with initially elevated blood pressure also had a steeper increase in systolic blood pressure during exercise as compared to normotensive diabetic patients. Also, in comparison to healthy control subjects the mean increase in systolic blood pressure was higher in group 1. The administration of enalapril did not significantly reduce the rise in blood pressure during exercise either among the patients with more marked blood pressure reactions (group 1) or in the other group (2). Although these data should be interpreted with some caution due to the small number of patients, they further support the hypothesis that ACE-inhibition probably affects renal function by an additive mechanism, i. e. not only by a decrease in systemic blood pressure. This is in accordance with other recently published results [12].

In conclusion, one could speculate that the effect of enalapril on AER is mediated by several different mechanisms in adolescent Type 1 diabetic patients. In patients with elevated blood pressure the decrease in blood pressure is a probable cause of the reduction in AER. In normotensive patients, a direct effect causing a reduction in microalbuminuria is proposed, which probably would result from a decrease in glomerular hypertension or a decrease in glomerular permeability to albumin. However, other biological effects independent of haemodynamic changes cannot be excluded. Long-term randomized follow-up studies of ACE inhibition initiated at an early stage of diabetes are necessary to evaluate not only the physiological effects but also the structural changes and effects on kidney growth.

Acknowledgements. The study was supported by grants from the Karolinska Institute Research Fund, "Förenade Liv" Mutual Group Life Insurance Company, Stockholm, Sweden, the Swedish Diabetes Foundation, the Swedish Diabetes Association, and Diabetes Foundation, Swedish Hoechst. We also thank M.Agren, E. Zettergren, G.M. Taube, and the staff at the Department of Paediatric Cardiology at St. Göran's Hospital for laboratory assistance.

\section{References}

1. Viberti GC, Hill RD, Jarrett RJ, Argyropaulos A, Mahmud Y, Keen H (1982) Microalbuminuria as a predictor of clinical nephropathy in insulin-dependent diabetes mellitus. Lancet I: 1430-1432

2. Mogensen CE, Christensen CK (1984) Predicting diabetic nephropathy in insulin-dependent patients. N Engl J Med 311: 89-93

3. Parving H-H, Hommel E, Mathiesen, Skott $\mathrm{P}$, Edsberg B, Bahnsen M, Lauritzen M, Hougaard P, Lauritzen E (1988) Prevalence of microalbuminuria, arterial hypertension, retinopathy 
and neuropathy in patients with insulin-dependent diabetes. $\mathrm{Br}$ Med J 296: 156-160

4. Mathiesen ER, Oxenboll B, Johansen K, Svendsen PA, Deckert T (1985) Incipient nephropathy in Type 1 (insulin-dependent) diabetes. Diabetologia 26: 406-410

5. Mogensen CE, Christensen CK (1985) Blood pressure changes and renal function in incipient and overt diabetic nephropathy. Hypertension 7: 64-73

6. Berglund J, Lins PE, Adamson U, Lins LE (1987) Microalbuminuria in long-term insulin-dependent diabetes mellitus. Prevalence and clinical characteristics in normotensive population. Acta Med Scand 222: 333-338

7. Christensen CK, Mogensen CE (1985) Effect of antihypertensive treatment on progression of incipient diabetic nephropathy. Hypertension 7: 109-113

8. Working group of hypertension (1987) Statement on hypertension. Diabetes Care 10: 764-776

9. Zats R, Dunn BR, Meyer TW, Anderson S, Rennke HG, Brenner BM (1986) Prevention of diabetic glomerulopathy by pharmacological amelioration of glomerular capillary hypertension. $\mathrm{J}$ Clin Invest 77: 1925-1930

10. Marre M, Chatellier G, Leblanc H, Guyene TT, Menard J, Passa P (1988) Prevention of diabetic nephropathy with enalapril in normotensive diabetics with microalbuminuria. Br Med J 297: 1092-1095

11. Insua A, Ribstein J, Mimran A (1988) Comparative effect of captopril and nifedipine in normotensive patients with incipient diabetic nephropathy. Postgrad Med J 64 [Suppl 3]: 59-62

12. Romanelli G, Giustina A, Cimino A, Valentini U, Agabitiosei E, Muiesan G, Giustina G (1989) Short term effect of captopril on microalbuminuria induced by exercise in normotensive diabetics. Br Med J 298: 284-288

13. Blood Pressure Measurements (1977) Prepared by the National Heart, Lung, and Blood Institute's Task Force on Blood Pressure Control in Children, Vol 59, No 5, part 2

14. Simsom DC (1988) Insulin sensitivity and the effects of antihypertensive agents: implications for the treatment of hypertension in the patient with diabetes mellitus. Postgrad Med J 64 [Suppl 3]: $39-47$

15. Rudberg S, Dahlquist G, Aperia A, Persson B (1988) Reduction of protein intake decreases glomerular filtration rate in young Type 1 (insulin-dependent) diabetic patients mainly in hyperfiltrating patients. Diabetologia 31: 878-883

16. Åstrand P-O, Rodahl K (1977) Textbook of Work Physiology. Physiological Bases of Exercise. 2nd edn. Mc Graw-Hill, USA, pp 289-361

17. Hilger HH, Klumper SD, Ullrich J (1958) Mikroanalytische Untersuchungen über die Wasser- und Natriumrückresorption aus den Sammelrohrenden der Säugetierniere. Pflügers Arch 267: 218-237

18. Smith HW, Finkelstein N, Aliminosa L, Crawford B, Graber M (1945) The renal clearances of substituted hippuric acid and derivates and other aromatic acids in dog and man. J Clin Invest 24 : 388-401

19. Dalton RN, Wiseman MJ, Turner C, Viberti GC (1988) Measurement of urinary para-aminohippuric acid in glycosuric diabetics. Kidney Int 34: 117-120
20. Gomeri J (1942) Modification of colorimetric phosphorous determination for the use with photoelectric colorimeter. J Lab Clin Med 27: 955-960

21. Friedman PJ, Dunn PJ, Jury DR (1986) Metoprolol and albumin excretion in diabetes. Lancet II: 1042-1043

22. Hommel E, Mathiesen E, Edsberg B, Bahnen M, Parving HH (1986) Acute reduction of arterial blood pressure reduces albumin excretion in Type 1 (insulin-dependent) diabetic patients with incipient nephropathy. Diabetologia 29:211-215

23. Taguma Y, Kitamoto Y, Futaki G, Ueda H, Monma H, Ishizaki M, Takahashi, Sekino H, Sasaki Y (1985) Effect of captopril on heavy proteinuria in azotemic diabetics. N Engl J Med 313: $1617-1620$

24. Parving H-H, Hommel E, Damkjaer Nielsen M, Giese J (1989) Effect of captopril on blood pressure and kidney function in normotensive insulin dependent diabetics with nephropathy. $\mathrm{Br}$ Med J 299: 533-536

25. Klahr S, Schreiner G, Ichikava I (1988) The progression of renal disease. N Engl J Med 318: 1657-1666

26. Raij L, Keane WF (1985) Glomerular mesangium: its function and relationship to angiotensin II. Am J Med 79: 24-30

27. Cooper ME, Allen TJ, Macmillan PA, Clarke BE, Jerums G, Doyle AE (1989) Enalapril retards glomerular basement membrane thickening and albuminuria in the diabetic rat. Diabetologia $32: 326-328$

28. Hollenberg NK, Meggs LG, Williams GH, Katz J, Garnic JD, Harrington DP (1981) Sodium uptake and renal responses to captopril in normal man and in essential hypertension. Kidney Int 20: 240-245

29. Mau Pedersen M, Schmitz A, Bjerregaard Pedersen E, Danielsen H, Sandhal Christiansen J (1988) Acute and long term renal effects of angiotensin converting enzyme inhibition in normotensive, normoalbuminuric insulin-dependent diabetic patients. Diabetic Med 5: 562-569

30. Kupin WC, Cortes P, Dumler F, Kilates MC, Lewin NW (1987) Effect on renal function of change from high to moderate protein intake in type 1 diabetic patients. Diabetes 36: 73-79

31. Wiseman MJ, Bognetti E, Dodds R, Keen H, Viberti GC (1987) Changes in renal function in response to protein restricted diet in Type 1 (insulin-dependent) diabetic patients. Diabetologia 30: 154-159

32. Feldt-Rasmussen B, Mathiesen ER, Deckert T (1986) Effect of two years strict metabolic control on the progression of incipient nephropathy in insulin-dependent diabetes. Lancet II: 13001304

33. Persson B, Thorén C (1980) Prolonged exercise in adolescent boys with juvenile diabetes mellitus. Acta Paediatr Scand [Suppl 283]: $62-69$

Received: 15 December 1989

and in revised form: 21 February 1990

Dr. S. Rudberg

Department of Paediatrics

St. Göran's Children's Hospital

S-11281 Stockholm

Sweden 